\title{
SIFAT FISIK DAN KIMIA SUP KRIM INSTAN DENGAN PENAMBAHAN HIDROLISAT PROTEIN DAGING KAMBING KACANG
}

\author{
1I. MIRDHAYATI DAN ${ }^{1}$ W. N. H. ZAIN \\ 1Laboratorium Teknologi Pascapanen \\ Fakultas Pertanian dan Peternakan Universitas Islam Negeri Sultan Syarif Kasim Riau \\ Kampus Raja Ali Haji Jl. H.R. Soebrantas KM. 15 Pekanbaru \\ Email:mirdhayati@gmail.com
}

\begin{abstract}
The protein hydrolysate from meat can be used as an ingredient in making instant cream soup. The application of protein hydrolysate from goat meat as an ingredient in making cream soup had never been done. The purpose of this study was to develop instant cream soup products based protein hydrolysate from goat meat as a functional food product prototype, and to know the characterization of instant cream soup in terms of its physical and chemical properties. This research was an experiment with a completely randomized design, with three replications. The treatment was the addition of protein hydrolysate from goat meat which consists of 6 concentration levels, namely, $0 \%, 0.2 \%, 0.4 \%, 0.6 \%, 0.8 \% 1.0 \%$ and commercial cream soup as a comparison. Data on physical properties and chemical composition were analyzed statistically by analysis of variance. The results showed that the addition of protein hydrolysate from goat meat at different concentrations was able to increase bulk density and $\mathrm{pH}$ value, but reduce the water holding capacity of instant cream soup produced. The addition of protein hydrolysate from goat meat at different concentrations increases the water content and protein content, decreases the carbohydrate content of instant cream soup, but did not effect the ash content and fat content. It can be concluded that the addition of protein hydrolysate from goat meat up to $1 \%$ concentration could produce instant cream soup had $\mathrm{pH}$ value and water holding capacity similar with commercial cream soup and could produced higher protein content than commercial product.
\end{abstract}

Keywords :, cream soup, goat meat, protein hydrolysate, physical and chemical properties

\section{PENDAHULUAN}

Dewasa ini ada kecenderungan peningkatan konsumen terhadap pangan fungsional khususnya berbahan dasar protein hewani. Hal ini berkaitan dengan semakin meningkatnya penyakit degeneratif di seluruh dunia, seperti peningkatan kejadian hipertensi dan kekurangan protein (Meinert et al., 2015). Pangan fungsional merupakan salah satu alternatif yang digunakan untuk mencegah dan mengobati penyakit tersebut karena selain zat gizi dan komponen bioaktif yang dikandungnya, sifat sensori yang dapat diterima, serta dapat dikonsumsi tanpa batasan dosis atau jumlah. Kelebihan ini tidak dijumpai pada obat-obatan maupun food suplement.

Produk pangan fungsional yang ada di Indonesia umumnya berasal dari negara-negara maju yang mempeloporinya seperti Jepang, Amerika Serikat dan negara-negara di kawasan
Eropa. Jenis produk pangan fungsional yang sudah dikembangkan dapat berupa susu antikolesterol, minuman antiaging, minuman antidiabetes, sup antihipertensi dan lain sebagainya. Umumnya produkproduk ini belum ada kepastian kehalalannya. Penelitian mengenai pengembangan produk pangan fungsional antihipertensi dalam negeri masih sangat terbatas. Penelitian pengembangan produk pangan fungsional dengan menggunakan bahan dan proses yang halal merupakan hal yang penting dilakukan.

Hidrolisat protein asal hewan dilaporkan memiliki aktivitas inhibitor angotensin converting enzyme (ACE) yang merupakan salah satu alternatif pengobatan hipertensi. Lebih lanjut, kandungan protein produk daging menjadi meningkat dengan adanya penambahan hidrolisat protein ke dalam produk, sehingga produk ini menjadi kaya 
protein dan dapat mengatasi kekurangan protein (Meinert et al., 2015).

Menurut Arihara dan Ohata (2008), hidrolisat protein daging dan peptida bioaktifnya sudah digunakan dalam produk daging fungsional. Hidrolisat ikan bonito kering yang mengandung peptida antihipertensi digunakan dalam produk sup di Jepang. Susu yang difermentasi juga mengandung peptida antihipertensi, dikenal tripeptida Ile-Pro-Pro dan ValPro-Pro yang terkandung dalam dua produk dairy komersil.

Berdasarkan hasil penelitian Mirdhayati et al. (2016), dilaporkan bahwa daging kambing kacang yang dihidrolisis dengan kombinasi enzim endo dan eksoprotease menghasilkan hidrolisat yang memiliki aktivitas inhibitor ACE. Lebih lanjut dijelaskan bahwa fraksi larut air hidrolisat daging kambing maupun hidrolisat sintetiknya juga memiliki aktivitas antihipertensi yang ditunjukkan dengan kemampuan menurunkan tekanan darah tikus gen hipertensi spontan. Dengan keunggulan ini, hidrolisat daging kambing kacang berpotensi sebagai ingredien fungsional yang dapat digunakan dalam pengembangan produk pangan fungsional.

Penelitian ini mengaplikasikan fraksi larut air hidrolisat protein daging kambing kacang sebagai ingredien fungsional yang digunakan dalam pembuatan sup krim instan. Dasar pertimbangannya adalah hidrolisat ini sudah terbukti secara in vitro dan in vivo sebagai senyawa antihipertensi dan memiliki rasa yang tidak pahit (Mirdhayati et al., 2016). Alasan pemilihan produk sup krim adalah hidrolisat protein lazim digunakan dalam pembuatan sup sehingga diharapkan mudah diterima konsumen selain sifat fungsional yang dimilikinya. Sejauh ini penelitian aplikasi hidrolisat protein daging kambing sebagai ingredien pembuatan sup krim belum pernah dilakukan. Hasil penelitian mengenai khasiat daging kambing kacang untuk kesehatan juga masih terbatas (Sutama dan Budiarsana, 2011).

Tujuan penelitian ini adalah untuk mengembangkan produk sup krim instan dari hidrolisat protein daging kambing sebagai prototype produk pangan fungsional. Penelitian ini juga bertujuan untuk mengetahui karakterisasi sup krim instan ditinjau dari komposisi kimia, $\mathrm{pH}$ dan sifat fisik yang meliputi densitas kamba dan daya mengikat air.

Manfaat yang diharapkan dari penelitian ini antara lain adalah diperolehnya suatu formulasi prototype sup krim instan yang menggunakan hidrolisat protein daging kambing kacang dan informasi karakteristik sup krim instan sebagai agen pangan fungsional antihipertensi.

\section{MATERI DAN METODE}

Penelitian ini dilaksanakan di Laboratorium Teknologi Pascapanen dan Laboratorium Nutrisi dan Kimia, Fakultas Pertanian dan Peternakan UIN Sultan Syarif Kasim Riau. Pelaksanaan penelitian ini berlangsung mulai dari bulan September sampai November 2016.

Bahan utama yang digunakan dalam penelitian ini adalah daging kambing kacang, enzim Flavourzyme, Protamex, akuades, dan bahan tambahan yang dibutuhkan dalam formulasi sup krim instan. Bahan lainnya adalah bahan kimia analytical grade yang dibutuhkan dalam analisis sifat fisik dan komposisi kimia. Peralatan yang digunakan antara lain adalah timbangan, waterbath shaker, termometer, kemasan aluminium, lemari pendingin, $\mathrm{pH}$ meter, peralatan untuk analisis sifat fisik dan komposisi kimia.

Penelitian ini bersifat eksperimen dengan rancangan percobaan dalam pembuatan sup krim adalah rancangan acak lengkap. Perlakuan dalam formulasi ini adalah penambahan hidrolisat protein daging kambing kacang yang terdiri atas 6 level konsentrasi yakni, $0 \%, 0,2 \%, 0,4 \%$, $0,6 \%, 0,8 \% 1,0 \%(b / b)$ dan sup krim 
komersil sebagai pembanding. Ulangan dilakukan sebanyak tiga kali. Rincian perlakuan formulasi sup krim instan ditunjukkan pada Tabel 1.

Tabel 1. Perlakuan formulasi sup krim instan dari hidrolisat protein daging kambing kacang

\begin{tabular}{lcccccc}
\hline \multirow{2}{*}{ Komponen } & \multicolumn{7}{c}{ Perlakuan Formulasi } \\
& F1 & F2 & F3 & F4 & F5 & F6 \\
\hline Hidrolisat daging kambing & 0,0 & 0,2 & 0,4 & 0,6 & 0,8 & 1,0 \\
Susu fullcream & 40 & 40 & 40 & 40 & 40 & 40 \\
Pati jagung & 42 & 41,8 & 41,6 & 41,4 & 41,2 & 41 \\
Garam & 3,6 & 3,6 & 3,6 & 3,6 & 3,6 & 3,6 \\
Lada putih & 1 & 1 & 1 & 1 & 1 & 1 \\
Gula pasir & 2 & 2 & 2 & 2 & 2 & 2 \\
Minyak jagung & 0,8 & 0,8 & 0,8 & 0,8 & 0,8 & 0,8 \\
Tepung bawang putih & 6,6 & 6,6 & 6,6 & 6,6 & 6,6 & 6,6 \\
Isolat protein kedelai & 2 & 2 & 2 & 2 & 2 & 2 \\
Monosodium glutamate & 2 & 2 & 2 & 2 & 2 & 2 \\
\hline
\end{tabular}

Prosedur penelitian dimulai dengan persiapan bahan baku yang meliputi pembuatan hidrolisat daging kambing. Prosedur pembuatan hidrolisat daging kambing mengacu kepada penelitian Mirdhayati et al. (2016).

\section{Pembuatan Hidrolisat Protein (Mirdhayati et al., 2016)}

Konsentrasi protease yang digunakan adalah $0,5 \%$ dan waktu hidrolisis selama 4 jam. Larutan daging dibuat dengan mencampurkan $100 \mathrm{~g}$ daging giling dan $300 \mathrm{~mL}$ air, kemudian dihomogenisasi menggunakan blender (National) selama 30 detik dan dituang ke dalam labu erlenmeyer $500 \mathrm{~mL}$. Larutan yang terbentuk dipanaskan dalam penangas air (GFL) pada suhu $85^{\circ} \mathrm{C}$ selama 30 menit dan kemudian didinginkan hingga suhu ruang $\left(27^{\circ} \mathrm{C}\right) \cdot \mathrm{pH}$ larutan awal diukur dengan $\mathrm{pH}$ meter (Milwawkee MW 801, Rumania), $\mathrm{pH}$ ditepatkan 7 dengan penambahan $\mathrm{NaOH} \quad 1 \quad \mathrm{~N}$. Hidrolisis dilakukan pada suhu $50^{\circ} \mathrm{C}$ dengan menggunakan inkubator bergoyang (Infors HT CH-4103 Bottmingen, Swiss). Hidrolisis pertama dilakukan dengan penambahan endoprotease pada konsentrasi $0,5 \%(\mathrm{~b} / \mathrm{b})$ ke dalam larutan daging yang dilakukan selama 60 menit. $\mathrm{pH}$ larutan dijaga konstan dengan penambahan $6 \mathrm{~N} \mathrm{NaOH}$ selama hidrolisis berlangsung dan dimonitor setiap 30 menit. Hidrolisis selanjutnya adalah dengan menambahkan protease kompleks ke dalam larutan daging dan hidrolisis dilakukan selama 3 jam. Kondisi hidrolisis adalah sama dengan hidrolisis pertama. Setelah waktu hidrolisis tercapai, dilakukan inaktivasi kedua protease dengan pemanasan pada suhu $85^{\circ} \mathrm{C}$ selama 30 menit dan didinginkan pada suhu ruang.

Hidrolisat yang terbentuk kemudian disentrifus dingin (Himac CR21G) pada kecepatan $11.900 \times \mathrm{g}$, dengan suhu $4^{\circ} \mathrm{C}$ selama 20 menit. Supernatan disaring dengan kertas saring dan dikumpulkan dalam erlenmeyer $500 \mathrm{~mL}$. pH supernatan diatur menjadi 7,0 dengan menggunakan $1 \mathrm{~N} \mathrm{NaOH}$ atau $\mathrm{HCl}$. Kemudian dilakukan pengukuran konduktivitas supernatan $(\mathrm{mS} / \mathrm{cm})$ untuk memonitor konsentrasi garam yang terkandung dalam hidrolisat. Supernatan selanjutnya dikeringkan dengan menggunakan alat pengering beku (Labconco/LYPH LOCK-18, Kansas) untuk mendapatkan bubuk hidrolisat.

\section{Pembuatan Sup Krim Instan}

Proses pembuatan sup krim instan mengacu kepada penelitian Sunyono dan Futiawati (2012) dan Mirdhayati (2004) yakni dengan metode dry mixing, dengan 
melakukan pencampuran semua bahan kering dan diaduk hingga tercampur merata. Tahap akhir adalah penambahan hidrolisat daging kambing menurut perlakuan ke dalam campuran bahan dan selanjutnya diaduk merata selama 15 menit. Sup krim instan yang diperoleh selanjutnya dikemas dalam kantong plastik, dikelim (sealing) dan dibungkus dengan kantong aluminium laminasi. Sup krim instan yang sudah dikemas, dimasukkan ke dalam kontainer plastik disimpan dalam lemari es pada suhu 5$6^{\circ} \mathrm{C}$ sampai dilakukan proses analisis.

\section{Parameter yang Diamati}

Parameter yang diamati adalah sifat fisik dan kimia sup krim instan. Sifat fisik meliputi densitas kamba dan daya mengikat air. Sifat kimia meliputi nilai $\mathrm{pH}$ dan komposisi kimia yang meliputi kadar air, kadar protein, kadar lemak, kadar abu dan karbohidrat.

1. Densitas Kamba

Cara kerja pengujian densitas mengacu kepada Wirakartakusumah dkk.(1992), sebanyak $10 \mathrm{~g}$ sampel sup krim ditimbang dan diukur volumenya dengan menggunakan gelas ukur $50 \mathrm{ml}$. Densitas Kamba dinyatakan dalam g/ml.

\section{Daya Mengikat Air}

Cara kerja pengujian daya mengikat air mengacu kepada Mirdhayati (2004) dengan modifikasi pada persiapan sampel. Sebanyak $1 \mathrm{~g}$ sup krim instant ditambah air sebanyak 11,25 $\mathrm{ml}$, diaduk merata dan kemudian dipanaskan sampai mendidih pada suhu $100 \mathrm{oC}$. Kemudian sup didinginkan sampai suhu $35 \mathrm{oC}$, dimasukkan dalam tabung sentrifus $15 \mathrm{ml}$ yang sudah diketahui beratnya. Tabung yang berisi sup krim disentrifugasi pada keccepatan 3000 rpm selama 15 menit. Supernatan sup krim dibuang, endapan yang tinggal pada tabung ditimbang beratnya.

Jumlah air yang diserap

$=[$ berat air awal - berat akhir (endapan) $]$ / berat awal x $100 \%$

\section{Komposisi Kimia}

Metode yang digunakan untuk menganalisis komposisi kimia sup krim instan ditunjukkan pada Tabel 2.

Tabel 2. Metode yang digunakan dalam menganalisis komposisi kimia

\begin{tabular}{ll}
\hline Analisis & Metode \\
\hline Air & AOAC $(2005)$ \\
Protein $(\mathrm{N})$ & AOAC $(2005 ; 960.52)$ \\
Lemak & AOAC (2005) \\
Abu & AOAC (2005) \\
Karbohidrat & By difference \\
\hline
\end{tabular}

\section{Analisis Data}

Data sifat fisik dan kimia yang diperoleh selanjutnya ditabulasi dalam bentuk tabel dan dianalisis secara statistik menggunakan analisis sidik ragam untuk mengetahui pengaruh penambahan hidrolisat daging kambing terhadap parameter yang diuji serta dilanjutkan uji lanjut Duncan Multiple Range Test untuk mengetahui perbedaan antara perlakuan.

\section{HASIL DAN PEMBAHASAN}

\section{Karakteristik Hidrolisat Protein Daging Kambing Kacang}

Pembuatan hidrolisat protein daging kambing kacang menggunakan kombinasi dua protease komersil yakni Protamex ${ }^{\circledR}$ (aktivitas 1,5 AU/g solid) dan Flavourzyme $^{\circledR}(500 \mathrm{U} / \mathrm{g})$ yang digunakan secara berurutan. Protamex ${ }^{\circledR}$ dengan nomor enzim 3.4.21.14 merupakan endoprotease yang berasal dari bakteri Bacillus, aktif pada kisaran $\mathrm{pH}$ 5,0-11 
dengan $\mathrm{pH}$ optimum 7,0 dan suhu 50 $60^{\circ} \mathrm{C}$. Flavourzyme ${ }^{\circledR}$ memiliki nomor enzim EC 3.4.11.1, merupakan protease kapang Aspergillus oryzae yang mengandung endo- dan eksoprotease, kondisi hidrolisis optimum pada kisaran $\mathrm{pH}$ 5,0-7,0 dan suhu $50^{\circ} \mathrm{C}$.

Hidrolisat protein daging kambing dalam bentuk kering yang dihasilkan pada penelitian ini berbentuk serbuk yang berwarna kuning kecokelatan disajikan pada Gambar 1. Hidrolisat tersebut diuji karakteristiknya yang meliputi kadar protein, kadar peptida, derajat hidrolisis dan aktivitas ACE inibitornya, yang ditunjukkan pada Tabel 3.

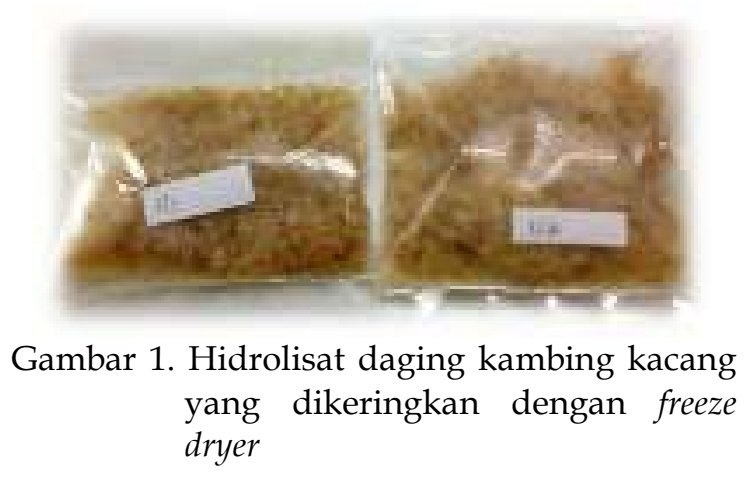

Tabel 3. Karakteristik hidrolisat protein daging kambing kacang

\begin{tabular}{lcc}
\hline Karakteristik & Nilai \pm standard deviasi & Sumber \\
\hline Kadar protein $(\% \mathrm{bb})$ & $73,45 \pm 3,06$ & *Min $10 \%$ \\
Kadar peptida $(\mathrm{mg} / \mathrm{g})$ & $406,61 \pm 22,59$ & - \\
Derajat hidrolisis $(\%)$ & $18,18 \pm 0,54$ & - \\
Aktivitas inhibitor ACE $(\%)$ & $58,50 \pm 2,74$ & - \\
Rendemen $(\%)$ & $51,78 \pm 2,74$ & - \\
\hline
\end{tabular}

Ket : * = SNI Sup krim instan Nomor 01-4967-1999

Berdasarkan Tabel 3, kadar protein hidrolisat daging kambing lebih besar dibandingkan dengan kadar protein hidrolisat lele dumbo yakni $53,29 \%$ bb (Widadi, 2011) dan hidrolisat ayam (mechanically deboned chicken) yakni $57,64 \%$ bb (Rossi et al., 2009). Perbedaan kadar protein hidrolisat tersebut diduga dapat disebabkan oleh perbedaan komposisi kimia, terutama kadar protein dari setiap bahan baku yang digunakan untuk menghasilkan hidrolisat. Selain itu, metode atau cara pembuatan hidrolisat juga diduga dapat mempengaruhi kadar protein hidrolisat yang dihasilkan. Wijayanti dkk. (2016) menyatakan hasil hidrolisis protein secara enzimatis berupa suatu hidrolisat yang mengandung peptida yang berat molekulnya lebih rendah dan asam amino bebas.

Kadar protein terlarut dan peptida berkaitan dengan aktivititas inhibitor ACE dari hidrolisat. Meskipun tidak selalu kadar protein terlarut dan peptida yang tertinggi akan menghasilkan hidrolisat dengan aktivitas inhibitor ACE tertinggi. Ghassem et al. (2011) menyatakan bahwa hidrolisat dengan kadar protein terlarut dan peptida yang tinggi tidak menghasilkan aktivitas inhibitor ACE yang tertinggi. Kadar peptida hidrolisat berguna sebagai variabel penentu dalam menentukan rasio efisiensi penghambatan.

Nilai derajat hidrolisis akan mempengaruhi aktivitas inhibitor ACE yang dihasilkan (Jang dan Lee, 2005; Chen et al. 2012). Aktivitas inhibitor ACE ini berasal dari peptida-peptida yang dihasilkan selama hidrolisis memiliki afinitas yang kuat dengan sisi aktif enzim ACE dan dapat mengganggu aktivitas katalitiknya sehingga menghambat aktivitas ACE dalam menghidrolisis substrat hippuril-histidil-leusin pada uji secara in vitro (Ryan et al. 2011).

\section{Sifat Fisik dan Nilai pH Sup Krim Instan}

Data sifat fisik dan nilai $\mathrm{pH}$ sup krim instan ditunjukkan pada Tabel 4. Uji sidik ragam menunjukkan bahwa penambahan 
hidrolisat protein daging kambing kacang pada konsentrasi berbeda mempengaruhi nilai rata-rata densitas kamba, daya mengikat air dan nilai $\mathrm{pH}$ sup krim instan yang dihasilkan. Tampilan sup krim instan ditunjukkan pada Gambar 2.

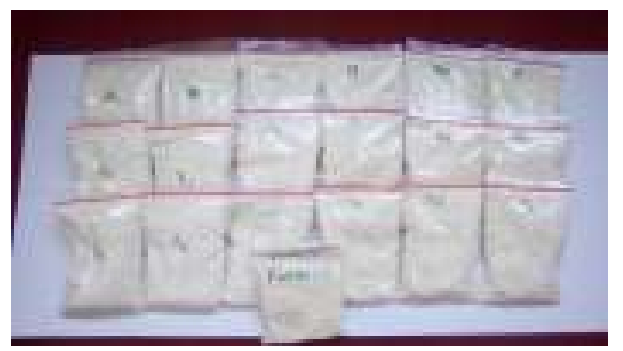

Gambar 2. Sup krim instan

Tabel 4. Sifat fisik dan nilai $\mathrm{pH}$ supkrim instan menurut perlakuan

\begin{tabular}{lccc}
\hline Sup krim & Densitas Kamba $(\mathrm{g} / \mathrm{ml})$ & Daya Mengikat Air $(\%)$ & Nilai pH \\
\hline Formulasi 1 & $0,67 \pm 0,05^{\mathrm{a}}$ & $44,85 \pm 1,39^{\mathrm{ab}}$ & $6,27 \pm 0,06^{\mathrm{a}}$ \\
Formulasi 2 & $0,63 \pm 0,02^{\mathrm{a}}$ & $46,43 \pm 6,25^{\mathrm{b}}$ & $6,34 \pm 0,05^{\mathrm{ab}}$ \\
Formulasi 3 & $0,64 \pm 0,01^{\mathrm{a}}$ & $44,57 \pm 2,19^{\mathrm{ab}}$ & $6,37 \pm 0,03^{\mathrm{b}}$ \\
Formulasi 4 & $0,66 \pm 0,04^{\mathrm{a}}$ & $35,01 \pm 2,59^{\mathrm{a}}$ & $6,36 \pm 0,01^{\mathrm{b}}$ \\
Formulasi 5 & $0,67 \pm 0,05^{\mathrm{a}}$ & $35,75 \pm 7,45^{\mathrm{a}}$ & $6.39 \pm 0,06^{\mathrm{b}}$ \\
Formulasi 6 & $0,66 \pm 0,01^{\mathrm{a}}$ & $36,71 \pm 3,50^{\mathrm{ab}}$ & $6,38 \pm 0,04^{\mathrm{b}}$ \\
Komersil (Knorr & $0,76 \pm 0,02^{\mathrm{b}}$ & $34,57 \pm 1,53^{\mathrm{a}}$ & $6,37 \pm 0,07^{\mathrm{b}}$ \\
\hline
\end{tabular}

Ket : Data disajikan dalam nilai rata-rata \pm standard deviasi.

Superskrip yang berbeda pada kolom yang sama menunjukkan berbeda nyata pada $\alpha=0,05$

Analisis sidik ragam (Tabel 4) menunjukkan bahwa penambahan hidrolisat protein daging kambing kacang pada konsentrasi sampai $1 \%$ nyata meningkatkan densitas Kamba dan nilai $\mathrm{pH}$ namun nyata menurunkan daya mengikat air sup krim yang dihasilkan. Uji lanjut Duncan menunjukkan bahwa nilai densitas kamba sup krim diantara semua formulasi adalah sama artinya penambahan hidrolisat protein daging kambing kacang sampai 1\% menghasilkan densitas kamba yang sama, namun produk komersil memiliki densitas kamba nyata lebih tinggi dibandingkan keenam formulasi sup krim yang dirancang pada penelitian ini. Hal ini diduga akibat perbedaan jenis dan jumlah ingredien yang digunakan oleh produk komersil berbeda dengan sup krim pada penelitian ini, sehingga menyebabkan densitas kamba berbeda. Menurut Wirakartakusumah (1992), densitas kamba menunjukkan kepadatan massa ingredien penyusun sup krim menempati suatu dimensi ruang. Kepadatan massa ditentukan oleh struktur dan ukuran bahan yang bercampur dalam menyusun matriks produk pangan yang dihasilkan. Densitas kamba yang kecil berarti bahan tersebut membutuhkan volume yang besar untuk sejumlah kecil bahan. Bahan pangan yang kamba akan membutuhkan tempat yang lebih luas dibandingkan dengan bahan yang densitas kambanya besar untuk berat bahan yang sama (Marta dan Tensiska, 2016).

Ditinjau dari daya mengikat air, uji lanjut Duncan menunjukkan bahwa daya mengikat air formula komersil sama dengan formulasi 1,3,4,5,6 dan cenderung lebih rendah dibandingkan formulasi 2, dan formulasi 2 memiliki nilai daya mengikat air yang sama dengan formulasi $1,3,6$. Kemampuan mengikat air produk sup krim sangat ditentukan oleh penambahan hidrolisat protein dan bahan pengisi yang digunakan dalam penelitian ini yakni pati jagung. Penambahan hidrolisat daging kambing sampai $1 \%$ dan pengurangan pati jagung sampai $1 \%$ cenderung menurunkan daya mengikat air. Hal ini berkaitan dengan sifat hidrolisat yang merupakan fraksi larut air dari hidrolisat daging kambing kacang yang sangat mudah larut air.

Ditinjau dari nilai $\mathrm{pH}$, uji lanjut Duncan menunjukkan bahwa formulasi sup krim tanpa penambahan hidrolisat 
daging kambing (formulasi 1) dan formulasi sup krim penambahan hidrolisat daging kambing konsentrasi $0,2 \%$ (formulasi 2) memiliki nilai $\mathrm{pH}$ produk sup krim yang lebih rendah dari formulasi sup krim dengan penambahan hidrolisat daging kambing konsentrasi $0,4 \%$ sampai $1 \%$ (formulasi $3,4,5,6$ ) dan produk komersil. Penelitian ini juga menunjukkan bahwa penambahan hidrolisat daging kambing konsentrasi 0,2\%-1\% menghasilkan $\mathrm{pH}$ produk yang sama dengan $\mathrm{pH}$ sup krim komersil. Peningkatan $\mathrm{pH}$ ini pada sup krim dengan penambahan hidrolisat daging kambing berkaitan dengan $\mathrm{pH}$ hidrolisat daging kambing yang digunakan yakni 7 , namun penambahan $0,2 \%-1 \%$ hidrolisat masih menghasilkan nilai $\mathrm{pH}$ sup krim yang sama di antara formulasi 2,3,4,5, dan 6.

\section{Komposisi Kimia}

Data komposisi kimia sup krim instan ditunjukkan pada Tabel 4. Uji sidik ragam menunjukkan bahwa penambahan hidrolisat protein daging kambing kacang pada konsentrasi berbeda meningkatkan nilai rata-rata kadar air dan kadar protein, namun menurunkan kadar karbohidrat sup krim instan yang dihasilkan, serta tidak mempengaruhi kadar abu dan kadar lemaknya.

Tabel 4. Komposisi kimia sup krim instan menurut perlakuan

\begin{tabular}{llcccc}
\hline Sup krim & Kadar Air & Kadar protein & $\begin{array}{c}\text { Kadar } \\
\text { Lemak }\end{array}$ & Kadar Abu & $\begin{array}{c}\text { Kadar } \\
\text { Karbohidrat }\end{array}$ \\
\cline { 2 - 6 } & & $\ldots \ldots \ldots \ldots \ldots \ldots \ldots \ldots .(\% \mathrm{bb}) \ldots \ldots \ldots \ldots \ldots \ldots \ldots \ldots$ \\
\hline Formulasi 1 & $5,26 \pm 1,00^{\mathrm{a}}$ & $7,31 \pm 0,41^{\mathrm{a}}$ & $2,65 \pm 0,58^{\mathrm{a}}$ & $6,95 \pm 1,05^{\mathrm{a}}$ & $77,83 \pm 0,42^{\mathrm{c}}$ \\
Formulasi 2 & $6,87 \pm 0,50^{\mathrm{bc}}$ & $8,09 \pm 0,17^{\mathrm{ab}}$ & $2,48 \pm 0,12^{\mathrm{a}}$ & $6,40 \pm 1,20^{\mathrm{a}}$ & $76,17 \pm 1,02^{\mathrm{b}}$ \\
Formulasi 3 & $6,26 \pm 0,31^{\mathrm{b}}$ & $7,72 \pm 0,52^{\mathrm{ab}}$ & $2,63 \pm 0,34^{\mathrm{a}}$ & $7,73 \pm 0,58^{\mathrm{a}}$ & $75,67 \pm 1,18^{\mathrm{ab}}$ \\
Formulasi 4 & $7,06 \pm 0,24^{\mathrm{bc}}$ & $8,25 \pm 0,76^{\mathrm{b}}$ & $3,03 \pm 0,46^{\mathrm{a}}$ & $6,53 \pm 0,70^{\mathrm{a}}$ & $75,13 \pm 0,97 \mathrm{ab}$ \\
Formulasi 5 & $7,25 \pm 0,11^{\mathrm{c}}$ & $7,86 \pm 0,40^{\mathrm{ab}}$ & $2,59 \pm 0,41^{\mathrm{a}}$ & $7,58 \pm 0,33^{\mathrm{a}}$ & $74,71 \pm 0,43^{\mathrm{ab}}$ \\
Formulasi 6 & $7,04 \pm 0,23^{\mathrm{bc}}$ & $9,23 \pm 0,43^{\mathrm{c}}$ & $2,59 \pm 0,47^{\mathrm{a}}$ & $7,18 \pm 1,05^{\mathrm{a}}$ & $73,97 \pm 1,16^{\mathrm{a}}$ \\
Komersil $\left(\text { Knorr }^{\circledR}\right)^{*}$ & - & 2 & 2 & - & 14 \\
\hline
\end{tabular}

Ket : Data disajikan dalam nilai rata-rata \pm standard deviasi.

Superskrip yang berbeda pada kolom yang sama menunjukkan berbeda nyata pada a 0,05.

* : berdasarkan informasi gizi pada kemasan produk.

Kadar karbohidrat dihitung berdasarkan by difference (100-(k.air+k.protein+k.abu+k.lemak)

Uji lanjut Duncan menunjukkan bahwa penambahan hidrolisat daging kambing $0,2 \%-1 \%$ nyata meningkatkan kadar air sup krim dibandingkan formulasi tanpa penambahan hidrolisat daging kambing. Kadar air sup krim menurut SNI maksimal sebesar $8 \%$ dan hasil penelitian sup krim yang diberi $0,2-$ $1,0 \%$ hidrolisat protein daging memiliki kadar air sebesar $6,87-7,25 \%$. Hal ini menunjukkan sup krim memiliki kadar air memenuhi standar mutu yang ditetapkan. Kadar air berkisar antara 3-7\% menurut Winarno (2002) dapat mengurangi reaksi kimia yang dapat merusak pangan seperti hidrolisis dan oksidasi lemak.
Uji lanjut Duncan menunjukkan bahwa penambahan hidrolisat daging kambing konsentrasi 1\% (formulasi 6) menghasilkan kadar protein sup krim paling tinggi dibandingkan formulasi $1,2,3,4$ dan 5. Peningkatan kadar protein sup krim disebakan oleh peningkatan konsentrasi hidrolisat protein daging kambing kacang, yang memiliki kadar protein $73,45 \%$ ( Tabel 3). Kadar protein sup krim instan pada formulasi 6 penambahan $1,0 \%$ hidrolisat protein daging sudah mendekati standar mutu sup krim, yaitu minimum $10 \%$.

Kadar abu dan lemak yang tidak berbeda diantara semua formulasi 
berkaitan dengan komposisi awal dalam penyusunan bahan pembuatan sup krim. Hasil penelitian ini juga menunjukkan peningkatan konsentrasi hidrolisat daging kambing kacang yang ditambahkan menghasilkan kandungan karbohidrat yang semakin menurun. Hal ini berkaitan dengan pengurangan jumlah pati jagung yang digunakan sebagai bahan pengikat. Pada formulasi terlihat bahwa semakin tinggi jumlah hidrolisat yang ditambahkan akan mengurangi jumlah pati yang digunakan dalam urutan jumlah yang sama. Kadar karbohidrat sup krim yang diberi hingga 1,0\% hidrolisat protein daging memiliki kadar yang sama dengan hasil penelitian Irwan (2017), yang mengembangkan sup kirm instan berbahan baku betakaroten dari labu kuning, yaitu sebesar 74,4\% (bb).

Berdasarkan sifat fisik, nilai $\mathrm{pH}$ dan komposisi kimia yang dilakukan, penambahan hidrolisat protein daging kambing kacang dalam pembuatan sup krim instan menghasilkan beberapa formulasi yang memiliki sifat fisik yang sama dengan produk komersil. Perbedaan jumlah dan jenis bahan penyusun sup krim dan perlakuan penambahan hidrolisat protein daging kambing kacang dalam pembuatan sup krim instan menyebabkan kadar protein keenam formulasi lebih tinggi dari produk komersil.

\section{KESIMPULAN}

Penambahan hidrolisat protein daging kambing kacang dalam pembuatan sup krim instan sampai konsentrasi 1\% menghasilkan densitas kamba yang lebih rendah dari produk komersil namun memiliki daya mengikat air dan $\mathrm{pH}$ yang sama dengan produk komersil. Penambahan hidrolisat protein daging kambing kacang dalam pembuatan sup krim instan sampai konsentrasi 1\% mampu meningkatkan kadar air dan kadar protein, menurunkan kadar karbohidrat serta tidak mengubah kadar abu dan kadar lemaknya. Kadar air sup krim instan dari semua formulasi memenuhi kriteria SNI 01-4967-1999 tentang sup krim instan namun hanya formulasi 6 (penambahan hidrolisat 1\%) yang memiliki kadar protein mendekati SNI. Perlakuan terbaik dari sifat fisik dan kimia adalah formulasi 6 ditinjau dari kadar air, kadar protein, daya mengikat air dan $\mathrm{pH}$.

\section{DAFTAR PUSTAKA}

[AOAC] Association Official Analytical Chemist's Technical Standard. 2005. Official Methods of Analysis, 16th ed. Washington.

[BSN] Badan Standardisasi Nasional. 1999. Sup Krim Instan. Standard Nasional Indonesia, SNI No. 01-4967-1999.

Arihara K., and M. Ohata 2008. Bioactive compounds in meats. In Fidel Toldra (Ed). Meat Biotechnology. Springer, New York. pp. 231-249.

Chen J, Y. Wang, Q. Zhong, Y. Wu, and W. Xia. 2012. Purification and characterization of a novel angiotensin- $\mathrm{i}$ converting enzyme (ACE) inhibitory peptide derived from enzymatic hydrolysate of grass carp protein. J. Peptides. 33 : 52-58.

Ghassem M, .K Arihara, A.S. Babji, M. Said and S. Ibrahim. 2011. Purification and identification of ACE inhibitory peptides from Haruan (Channa striatus) myofibrillar protein hydrolysate using HPLC-ESI-TOF MS/MS. Food Chem. 129:1770-1777.

Irwan, W.S. 2017. Pengembangan produk krim sup instan tinggi betakaroten berbasis labu kuning (Cucurbita moschata) untuk lanjut usia (Lansia). Tesis. Sekolah Pascasarjana. Institut Pertanian Bogor. Bogor.

Jang A., and M. Lee. 2005. Purification and identification of angiotensin converting enzyme inhibitory peptides from beef hydrolysates. Meat Sci. 69 : 653-661. 
Marta, H. and Tensiska. 2016. Kajian Sifat Fisikokimia Tepung Jagung Pragelatinisasi serta Aplikasinya pada Pembuatan Bubur Instan. Jurnal Penelitian Pangan. 1(1) : 14-21.

Meinert L, E.H. de Lichtenberg Broge, C. Bejerholm, K. Jensen. 2015. Application of hydrolyzed protein of animal origin in processed meat. Food Sci \& Nutrition. 4(2) : 290-297.

Mirdhayati, I. 2004. Formulasi dan karakterisasi sifat-sifat fungsional bubur garut (Maranta arundinaceae Linn) instan sebagai makanan pendamping air susu ibu (MP-ASI). Tesis. Sekolah Pascasarjana, Institut Pertanian Bogor. Bogor.

Mirdhayati, I, J. Hermanianto, C.H. Wijaya, D. Sajuthi dan K. Arihara . 2016. Angiotensin converting enzyme (ACE) inhibitory and antihypertensive activities of protein hydrolysate from meat of kacang goat (Capra aegagrus hircus). J. Sci. Food Agric. 96:3536-3542. Wileyonlinepublication. Doi : 10.1002/JSFA.7538.

Rossi, D.M., S.H. Flôres, J.X. Heck and M.A.Z Ayub. 2009. Production of High-protein Hydrolysate from Poultry Industry Residue and their Molecular Profiles. Food Biotechnology. 23(3) : 229-242. DOI: 10.1080/08905430903102828.
Ryan, J.T, R.P. Ross, D. Bolton, G.F. Fitzgerald, and C. Stanton. 2011. Bioactive peptide from muscle sources: meat and fish. Journal of Nutrients. $3: 765-791$.

Sunyoto, M, and R. Futiawati. 2012. The influence of fullcream milk powder concentration on the charactheristic of "Rasi" instant soup cream. J.Agric Sci \&Technol. A2 : 1218-1231.

Sutama, I.K., dan I.G.M. Budiarsana. 2011. Panduan lengkap Kambing dan Domba. Edisi ketiga. Penebar Swadaya. Jakarta. 203hlm.

Widadi, I.R. 2011. Pembuatan dan Karakterisasi Hidrolisat Protein dari Ikan Lele Dumbo (Clarias gariepinus) Menggunakan Enzim Papain. Skripsi. Fakultas Perikanan dan Ilmu Kelautan IPB. Bogor.

Wijayanti, I., Romadhon, L. Rianingsih. 2016. Karakteristik Hidrolisat Protein Ikan Bandeng (Chanos chanos Forsk) dengan Konsentrasi Enzim Bromelin yang Berbeda. Jurnal Saintek Perikanan. 11(2) : 129-133.

Wirakartakusumah, M.A., K. Abdullah dan A.M. Syarief. 1992. Sifat Fisik Pangan. PAU Pangan Gizi IPB, Bogor. Hal: 26-31. 